\title{
PEMETAAN DAYA SAING PRODUK PERIKANAN PULAU JAWA DI PASAR TUJUAN UTAMA
}

\section{Mapping The Competitiveness of Java Island Fishery Products In Main Destination Market}

\author{
Andhatu Achsa, Rian Destiningsih*, Yustirania Septiani, Dian Marlina Verawati \\ Universitas Tidar \\ Jl. Kapten Suparman No.39, Tuguran, Potrobangsan, Kec. Magelang Utara, Kota Magelang, Jawa \\ Tengah 56116
}

Diterima tanggal: 10 Oktober 2020 Diterima setelah perbaikan: 18 November 2021

Disetujui terbit: 20 Desember 2020

\begin{abstract}
ABSTRAK
Penelitian ini dilatarbelakangi adanya penurunan nilai ekspor perikanan yang terjadi di tahun 2003 hingga 2016, walaupun setelah itu mengalami peningkatan kembali. Hal tersebut diduga terjadi karena kuantitas ekspor perikanan mengalami penurunan sebesar -0,15 persen. Adapun usaha awal mencegah penurunan ekspor perikanan semakin berkepanjangan yaitu dengan mengidentifikasi wilayah produksi perikanan yang memiliki keunggulan komparatif dan kompetitif. Dalam hal ini, sentra perikanan dibagi menjadi dua kelompok yaitu perikanan tangkap dan perikanan budi daya. Metode yang digunakan antara lain Shiftshare Esteban Marquilas (SS-EM), Revealed Comparative Advantage (RCA) dan metode Ekspor Produk Dinamika (EPD). Hasil penelitian menunjukkan daya saing perikanan hanya ada pada provinsi DIY; sedangkan provinsi lainnya hanya memiliki spesialisasi. Selanjutnya, daya saing perikanan Indonesia pada ketujuh pasar tujuan utama ekspor perikanan yaitu Tiongkok, Jepang, Hongkong, Amerika Serikat, Malaysia, Uni Eropa dan ASEAN memiliki daya saing kuat. Selanjutnya, produk perikanan Indonesia selama tahun 2000-2018 tergolong rising star pada pasar Malaysia, Tiongkok dan Amerika Serikat.
\end{abstract}

Kata Kunci: daya saing; keunggulan komparatif; perikanan; shiftshare

\begin{abstract}
The decrease of fisheries export values from 2003 to 2016 initiated this research. Despite its increasing afterwards, the decreasing is presumed due to the decrease of export quantities by -0.15 percent. Initial effort to prevent on decreasing of export quantities is identifying fisheries production centers with comparative and competitive advantages. Fisheries production centers are divided into two groups: capture fisheries and aquaculture. Shiftshare Esteban Marquilas (SS-EM), Revealed Comparative Advantage (RCA) and Export Product Dynamics (EPD) methods are employed in this research. The results indicate that fisheries competitiveness is only seen in Yogyakarta, while other provinces only have specialization in fisheries. It is notified that competitiveness of Indonesian fisheries products is considered strong in seven market destination: China, Japan, Hongkong, United States, Malaysia, European Union, and ASEAN countries. Furthermore, Indonesian fisheries products in 2000 - 2018 has been acknowledged as rising star in several market destination: Malaysia, China and United States.
\end{abstract}

Keywords: competitiveness; comparative advantage; fisheries; shiftshare

\section{PENDAHULUAN}

Perdagangan internasional dilakukan guna mencapai tujuan pembangunan nasional yang didukung dengan sumberdaya, teknologi, aksesbilitas transportasi yang maju. Negara yang memiliki keunggulan dapat bersaing di kancah internasional. Indonesia dalam hal perdagangan internasional sudah mengikuti beberapa kesepakatan antar negara misalnya Masyarakat Ekonomi ASEAN (MEA) yang dilaksanakan pada tahun 2015 merupakan program bagi negaranegara ASEAN dalam peningkatan perekonomian khususnya perdagangan (Malau, 2014). Pilar 
utama dalam cetak biru MEA 2015 antara lain pembentukan pasar tunggal dan basis produksi. Tujuan mengarah pada arus bebas barang, jasa, investasi, pekerja dan arus modal antar Negara, pada awalnya ditetapkan dua belas bidang dimana hampir setengah mewakili transakasi antar negara ASEAN. Bentuk pekerjaan tersebut yakni terkait pengelolaan pertanian, industri komoditi karet, industri komoditi kayu,penerbangan, mesin, elektronik, teknologi informasi dan komunikasi, perikanan, kesehatan, logistik, tekstil, dan pariwisata et al., 2015). Tujuan lainnya adalah sebgai persatuan dasar produksi ASEAN untuk mendukung arus bebas barang, jasa, tenaga kerja dan modal (investasi). MEA menjadi harapan di kawasan ekonomi karena mampu meningkatkan daya saing tinggi, serta menjadi kawasan yang terintegrasi dengan ekonomi global.

Kunci perdagangan internasional negara adalah memiliki sektor atau komoditas yang memiliki keunggulan kompetitif dan atau komparatif. Teori daya saing menurut David Ricardo dikembangkan dalam konsep keunggulan komparatif. Ricardo menjelaskan spesialisasi produksi pada komoditi tertentu didasari akan keunggulan komparatif suatu negara yang terbentuk dari kemampuan teknologi yang dimiliki (Arifin et al., 2007). Negara pengekspor dapat memproduksi jika dianggap memberikan kerugian absolut terkecil atau negara tersebut memiliki keunggulan komparatif, tetapi negara akan menjadi pengimpor jika tidak memiliki keunggulan komparatif atas barang tersebut (Salvatore, 2014). Teori daya saing, Michael E. Porter, adalah daya saing domestik yang tinggi akan mendorong terciptanya keunggulan kompetitif dalam suatu Negara (Sarwono \& Pratama, 2014). Daya saing merupakan kemampuan produsen dalam produksi untuk mengasilkan komoditas yang bermutu, biaya produksi rendah agar ketika barang tersebut dipasarkan dapat memperoleh laba yang mencukupi sehingga mampu mempertahankan kelanjutan kegiatan produksinya (Wulansari et al., 2016).

Indonesia sebagainegara maritim mempunyai potensi kekayaan sumberdaya perikanan yang dapat menyerap tenaga kerja dibidang perikanan (Triarso, 2012). Perikanan merupakan salah satu sektor andalan pembangunan ekonomi Indonesia karena sebagian besar masyarakat Indonesia menjadikan sektor ini sebagai sumber penghidupan (Amarullah, 2017). Perikanan menjadi sumber pendapatan negara sekaligus sumber pendapatan masyarakat, khususnya nelayan. Posisi Indonesia sebagai penghasil produk perikanan dunia untuk perikanan tangkap laut berada di urutan ke-2, perikanan tangkap darat di urutan ke-7, dan budidaya ke-3 di dunia (Direktorat Kelautan dan Perikanan, 2016).

Ditinjau dari nilai ekspor perikanan Indonesia tahun 2011-2018 cenderung mengalami penurunan (Gambar 1), dimana penurunan tertinggi pada 2015 mencapai 15 persen. Hal tersebut diduga terjadi karena nilai tukar yang meningkat. Kestabilan nilai tukar memudahkan eksportir dalam pengiriman barang ke luar negara (Risma et al., 2018). Negara tujuan utama ekspor perikanan antara lain Amerika Serikat, Jepang, Asean, China, Malaysia, Hongkong dan Uni Eropa. Produksi perikanan di

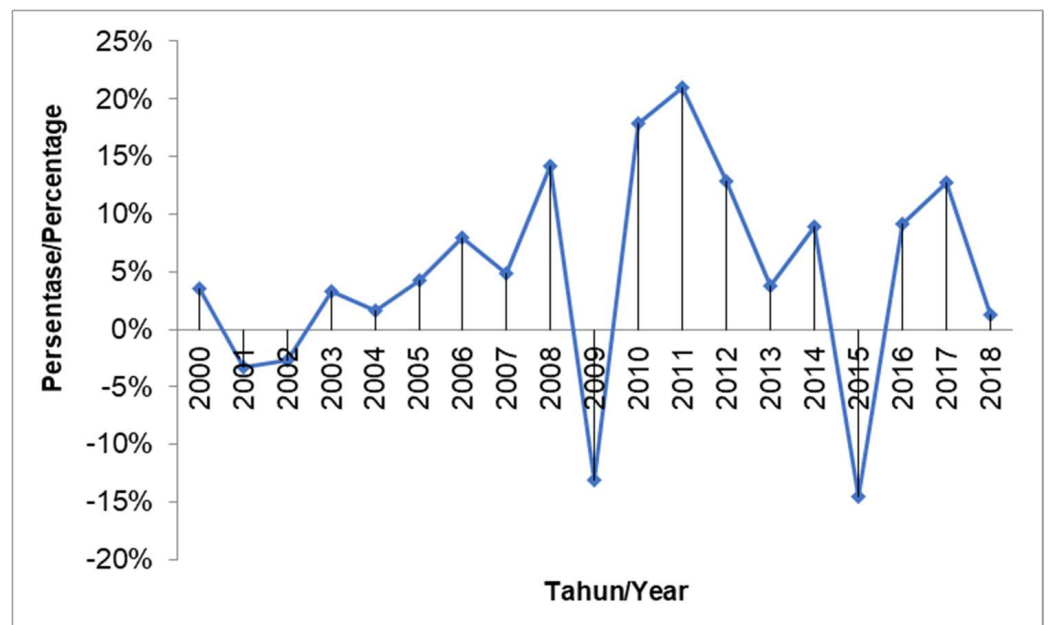

Gambar 1. Laju Perkembangan Ekspor Perikanan (HS 03) Tahun 2000-2018.

Figure 1. Fishery Export Development Rate (HS 03) 2000-2018

Sumber: UN COMTRADE, 2020/ Source: UN COMTRADE, 2020 


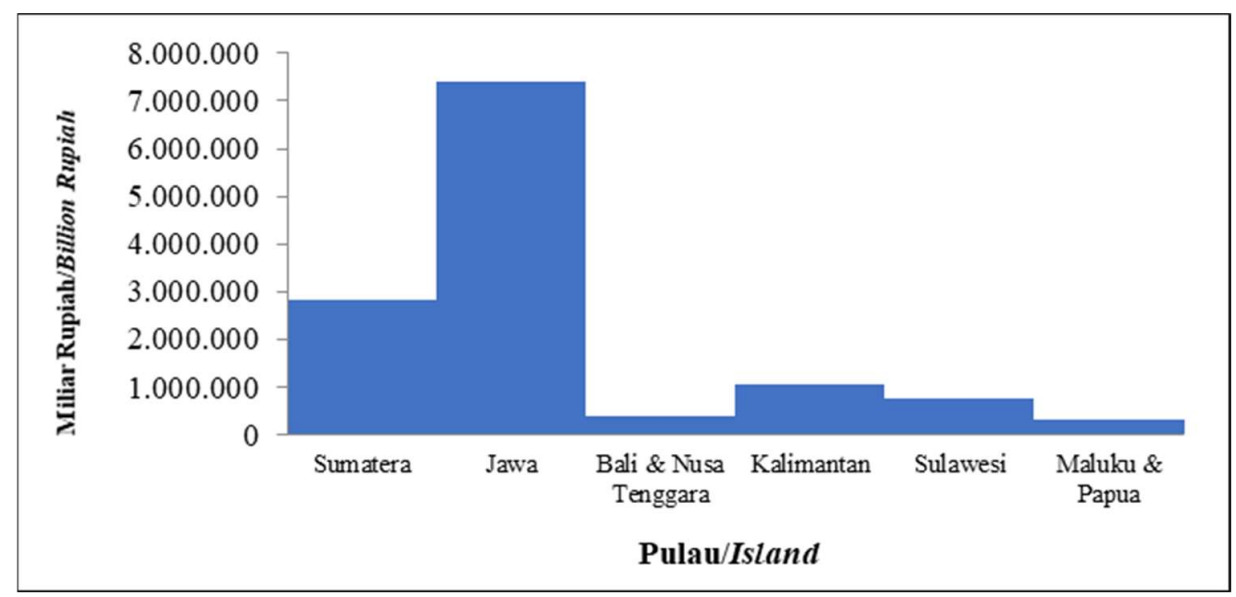

\section{Gambar 2. Rata-rata PDRB Atas Dasar Harga Berlaku di Pulau-pulau Indonesia Tahun 2014-2018 (Miliar Rupiah).}

Figure 2. Average GRDP at Current Price in Indonesian Islands 2014-2018 (in billions of Rupiah) Sumber: Badan Pusat Statistik Indonesia, 2020/ Source: BPS - Statistics Indonesia 2020

Indonesia tahun 1999-2017 cenderung meningkat baik capture fisheries dan aquaculture.

Pulau Jawa dengan luas 6,74 persen dari total luas Indonesia. PDRB rata-rata tertinggi dari pulau-pulau di Indonesia adalah Jawa, diikuti oleh Sumatera, Kalimantan, Sulawesi, Bali \& Nusa Tenggara, dan Maluku dan Papua. Produksi perikanan di Pulau Jawa mengalami penurunan tahun 2002-2005, penurunan tersebut terjadi sangat tajam pada tahun 2004 sebesar minus 42,67 persen (Gambar 2). Secara umum perkembangan produksi perikanan di Pulau Jawa pada tahun 2000-2018 terlihat peningkatan kuantitas ekspor perikanan mengalami peningkatan sebesar 130,3 persen.
Seiring dengan peningkatan produksi perikanan, pemerintah melalui Kementerian Kelautan dan Perikanan (KKP) melakukan kampanye konsumsi ikan. Kementerian Kelautan dan Perikanan telah berupaya untuk mempercepat pembangunan sektor perikanan melalui peningkatan industri perikanan yang bertujuan untuk meningkatkan kualitas, kuantitas, nilai tambah, dan daya saing hasil perikanan, serta meningkatkan pendapatan dan kesejahteraan masyarakat. semua pelaku di sektor perikanan (Imelda et al., 2019). Rata-rata konsumsi ikan di pulau Jawa tercatat 20-31,4 kg / kap. Pulau Jawa dimana didalamnya ada provinsi Jawa Barat, Jawa Tengah, Jawa Timur, DKI Jakarta, DI. Yogyakarta

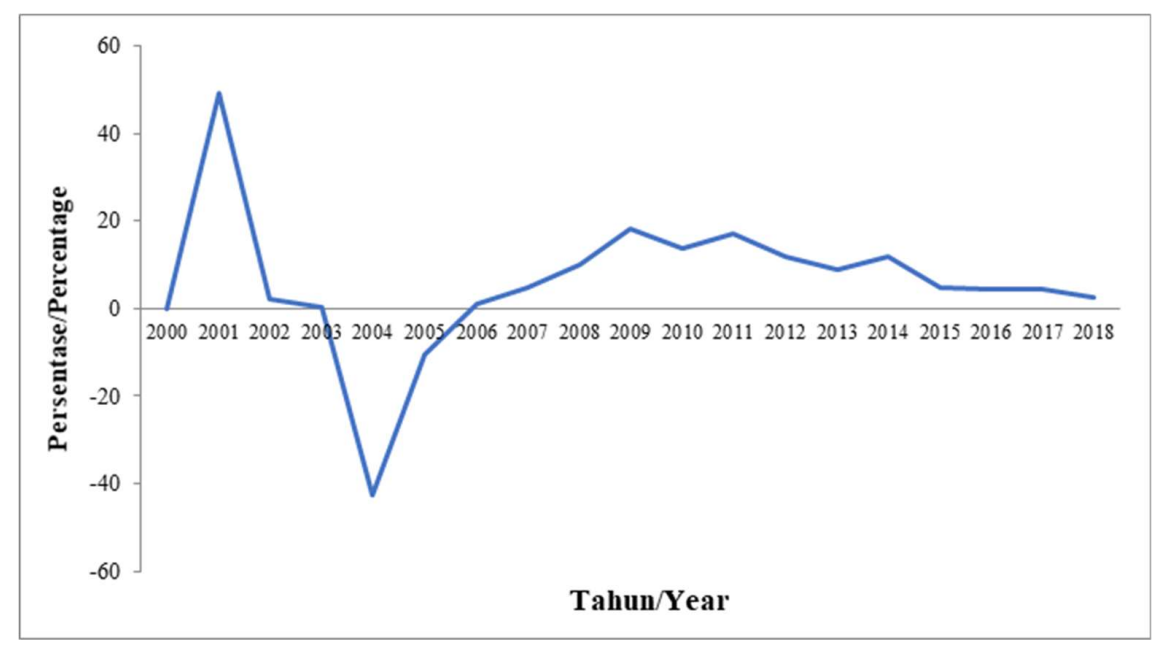

Gambar 3. Laju Perkembangan Ekspor Perikanan (HS 03) Tahun 2000-2018.

Figure 3. Fishery Export Development Rate (HS 03) 2000-2018

Sumber: Badan Pusat Statistik Indonesia, 2020/ Source: BPS - Statistics Indonesia 2020 
dan Banten; memperlihatkan dua dari tiga provinsi tersebut merupakan provinsi dengan pelabuhan utama perikanan pada tahun 2011-2018, yaitu DKI Jakarta dan Jawa Timur (Indonesia, 2019). Jumlah ekspor tertinggi untuk komoditas perikanan tangkap berturut-turut ditempati oleh DKI Jakarta, Bali dan Jawa Timur. Sedangkan untuk budidaya perikanan, DKI Jakarta menempati urutan kedua disusul Jawa Timur. Tujuan dari penelitian ini yaitu untuk mengidentifikasi keunggulan komparatif dan kompetitif perikanan melalui perikanan tangkap dan budidaya di pulau Jawa; identifikasi daya saing perikanan Indonesia ke tujuh tujuan utama ekspor; serta peta daya saing perikanan di Pulau Jawa dan Indonesia secara umum ke tujuh negara tujuan ekspor utama tahun 2000-2018.

\section{METODOLOGI}

\section{Lokasi dan Waktu Penelitian}

Penelitian berlangsung di seluruh provinsi yang ada di Pulau Jawa yakni Provinsi Jawa Barat, Jawa Tengah, Jawa Timur, DKI Jakarta, DIY dan Banten. Periode penelitian dilaksanakan tahun 2000 sampai dengan 2018.

\section{Jenis dan Metode Pengambilan Data}

Penelitian ini merupakan multi disiplin ilmu antara ekonomi perencanaan dan ekonomi pertanian. Sumber data dalam penelitian yaitu dari Badan Pusat Statistik provinsi-provinsi di Pulau Jawa, Kementerian Kelautan dan Perikanan Republik Indonesia, Bank Dunia dan Food and Agriculture Organization of the United Nations (FAO) 2000 hingga 2018. Data yang diperlukan diantaranya produksi perikanan khususnya capture fisheries dan aquaculture di provinsi-provinsi Pulau Jawa; nilai ekspor dan impor capture fisheries dan aquaculture Indonesia; nilai ekspor dan impor capture fisheries dan aquaculture di Indonesia, Amerika Serikat, Jepang, Asean, China, Malaysia, Hongkong dan Uni Eropa; nilai ekspor dan impor capture fisheries dan aquaculture di dunia; informasi kebijakan-kebijakan terkait perikanan di Indonesia.

\section{Metode Analisis}

Alat analisis yang digunakan yaitu Shiftshare Esteban Marquilas, analisis Revealed Comparative Advantage (RCA) dan metode Ekspor Produk Dinamika (EPD). Dalam analisis shiftshare Esteban Marquilas (SS E-M) terdapat empat kategori yaitu ketika (1) Eij-E'ij > 0 dan rij-rin > 0, artinya perikanan (capture fisheries dan aquaculture ) termasuk sektor kompetitif dan terspesialisasi, (2) Eij-E'ij > 0 dan rij-rin $<0$, artinya perikanan (capture fisheries dan aquaculture ) termasuk sektor tidak kompetitif dan terspesialisasi, (3) Eij-E'ij < 0 dan rij-rin > 0, artinya perikanan (capture fisheries dan aquaculture ) termasuk sektor kompetitif dan tidak terspesialisasi, (4) Eij-E'ij < 0 dan rij-rin < 0, artinya perikanan (capture fisheries dan aquaculture) termasuk sektor tidak kompetitif dan tidak terspesialisasi. Sedangkan dalam analisis Revealed Comparative Advantage (RCA) terdapat dua kategori yaitu ketika nilai RCA>1 artinya suatu negara memiliki keunggulan komparatif di atas rata-rata dunia sehingga sektor perikanan (capture fisheries dan aquaculture) memiliki daya saing kuat, dan nilai $\mathrm{RCA}<1$ berarti suatu negara memiliki keunggulan komparatif dibawah rata-rata dunia atau dengan kata lain sektor perikanan (capture fisheries dan aquaculture) memiliki daya saing yang lemah. Kemudian dalam analisis Ekspor Produk Dinamika (EPD) terdapat empat kategori yaitu (1) posisi rising star merupakan posisi yang ideal dan mempunyai posisi tertinggi pada ekspornya, (2) posisi lost opportunity terkait dengan posisi penurunan pangsa pasar pada produk atau komoditasnya yang dinamis, (3) posisi falling star merupakan posisi yang lebih baik dibandingkan dengan posisi lost opportunity karena kondisi pangsa ekspor totalnya masih memiliki pertumbuhan yang positif meski mengalami penurunan di pangsa ekspor komoditasnya, dan (4) posisi retreat merupakan kondisi yang tidak berkompetitif dan cenderung mengalami pertumbuhan yang stagnan.

\section{HASIL DAN PEMBAHASAN}

Pulau Jawa dengan luas sebesar 6,74 persen dariluas Indonesia (Badan Pusat Statistik Indonesia, 2020). Pulau Jawa di kelilingi oleh perairan yang berbatasan dengan Samudera Hindia, Selat Bali, Selat Sunda dan Laut Jawa. Pulau Jawa memiliki luas sekitar $126.442,02 \mathrm{~km}^{2}$ dengan populasi sekitar 151.061.800 jiwa pada tahun 2019 (Badan Pusat Statistik Indonesia, 2020). Dengan jumlah populasi yang begitu besar menjadikan Pulau Jawa sebagai pulau yang padat dan terbanyak di Indonesia. Potensi perikanan laut yang dimiliki oleh laut Indonesia yang tersebar pada hampir di semua bagian perairan laut Indonesia yang ada seperti pada perairan laut teritorial, perairan nusantara dan laut Zona Ekonomi Eksklusif (ZEE). Potensi perikanan laut salah satunya ada di Laut Jawa. Potensi ikan di Laut Jawa sangat besar, 
yang bahkan mencapai 836.000 ton/tahun (BPS Jatim, 2015). Oleh karena itu perlu adanya peranan dari seluruh lapisan masyarakat Indonesia untuk menjaga potensi Laut Jawa yang tersisa. Dengan begitu untuk masa yang akan datang generasi penerus bangsa bisa tetap menikmati kekaayaan laut tersebut. Ikan sebagai sumber protein hewani yang cenderung relatif murah juga memiliki potensi dalam perbaikian gizi kurang.

Pulau Jawa sendri terdiri dari beberapa provinsi yang memiliki keanekaragaman jenis ikan lautnya. Produksi perikanan tangkap di Pulau Jawa sebesar 1.328.831 ton pada tahun 2018, produksi perikanan budi daya di Pulau Jawa sebesar 2.027.564 ton (BPS, 2020).

\section{ShiftShare Esteban Marquilas}

Perikanan tangkap terdiri dari perikanan tangkap laut serta perikanan perairan terbuka. Terjadi peningkatan produksi tangkapan, namun perkembangannya menemui kendala, antara lain keterbatasan ketersediaan atau sumber daya ikan, bahkan di beberapa wilayah di Indonesia terdeteksi adanya fenomena overfishing, illegal fishing yang dilakukan oleh kapal asing (Kementerian PPN / Bappenas \& Direktorat Kelautan dan Perikanan, 2014). Jika hasil tangkapan melebihi batas (eksploitasi berlebihan) sehingga tidak ada ikan yang tersisa di lautan untuk berkembang biak dan mengisi kembali populasi ikan, maka lautan tidak akan meninggalkan ikan pada tahun 2050 asalkan tidak dilakukan tindakan yang tepat (Jawaid et al., 2019). Sementara itu, upaya penangkapan ikan di laut lepas masih terhambat oleh fasilitas penangkapan ikan milik nelayan Indonesia. Peningkatan pengelolaan perikanan merupakan bentuk faktor penentu salah satu keberhasilan pembangunan perikanan tangkap yang berkelanjutan, berbasis potensi sumber daya ikan yang memperhatikan kearifan lokal dan peran masyarakat seperti konsep pengelolaan perikanan berbasis WPP harus didukung dengan peralatan pendukung yang memungkinkan, baik dari aspek fisik dan kelembagaan (Kusdiantoro et al., 2019). Produksi budidaya meliputi budidaya laut, budidaya tambak, budidaya tangki ikan, budidaya keramba, budidaya ikan apung, tambak sawah, dan budidaya perairan laut.

Shift Share Esteban Marquilas dilengkapi dengan komponen tambahan jika dibandingkan dengan Shift Share klasik, yaitu komponen efek lokasi atau pertumbuhan pangsa pasar yang nantinya akan dikategorikan menjadi komponen spesialisasi dan kompetitif. Berdasarkan hasil perhitungan di sektor perikanan yang dihasilkan oleh shiftshare Esteban Marquiles pada Tabel 1 untuk beberapa provinsi di Pulau Jawa, menunjukkan bahwa Provinsi DIY berada pada kuadran 1 yang artinya daerah tersebut memiliki keunggulan kompetitif dan sudah terspesialisasi. Sedangkan untuk Provinsi Jawa Barat, Jawa Tengah, Jawa Timur dan Banten berada pada kuadran 2, artinya daerah tersebut belum memiliki daya saing namun memiliki spesialisasi. Selanjutnya, DKI Jakarta berada pada kuadran 4, hal ini menunjukkan bahwa wilayah tersebut tergolong tidak kompetitif dan tidak terspesialisasi di sektor perikanan.

Tabel 1. ShiftShare Esteban Marquilas Provinsi-provinsi di Pulau Jawa tahun 2000-2018

Table 1. Shiftsahre Esteban Marquilas In Provinces Of Java Island In 2000-2018

\begin{tabular}{|c|c|c|c|c|}
\hline \multirow[t]{2}{*}{ Provinsi/ Province } & \multicolumn{2}{|c|}{$\begin{array}{c}\text { Komponen Efek Alokasi/ } \\
\text { Allocation Effect } \\
\text { Component (AE) }\end{array}$} & \multirow[t]{2}{*}{$\begin{array}{l}\text { Kuadran/ } \\
\text { Quadrant }\end{array}$} & \multirow[t]{2}{*}{ Keterangan/Note } \\
\hline & Eij-E’'ij & rij-rin & & \\
\hline DKI Jakarta/ DKI Jakarta & $(227,267.12)$ & $(20.89)$ & 4 & $\begin{array}{l}\text { Tidak kompetitif, tidak terspesialisasi/ } \\
\text { Not competitive, not specialized }\end{array}$ \\
\hline Jawa Barat/West Java & $1,491,009.23$ & $(14.15)$ & 2 & $\begin{array}{l}\text { Tidak kompetitif, terspesialisasi/ Not } \\
\text { competitive, specialized }\end{array}$ \\
\hline Jawa Tengah/Central Java & $4,847,529.78$ & (19.39) & 2 & $\begin{array}{l}\text { Tidak kompetitif, terspesialisasi/ Not } \\
\text { competitive, specialized }\end{array}$ \\
\hline Jawa Timur/East Java & $1,895,631.73$ & $(5.07)$ & 2 & $\begin{array}{l}\text { Tidak kompetitif, terspesialisasi/ Not } \\
\text { competitive, specialized }\end{array}$ \\
\hline Banten/Banten & $355,404.58$ & $(16.14)$ & 2 & $\begin{array}{l}\text { Tidak kompetitif, terspesialisasi/ Not } \\
\text { competitive, specialized }\end{array}$ \\
\hline DIY/ DIY & $4,300.85$ & 21.48 & 1 & $\begin{array}{l}\text { kompetitif, dan terspesialisasi/ } \\
\text { competitive, specialized }\end{array}$ \\
\hline
\end{tabular}




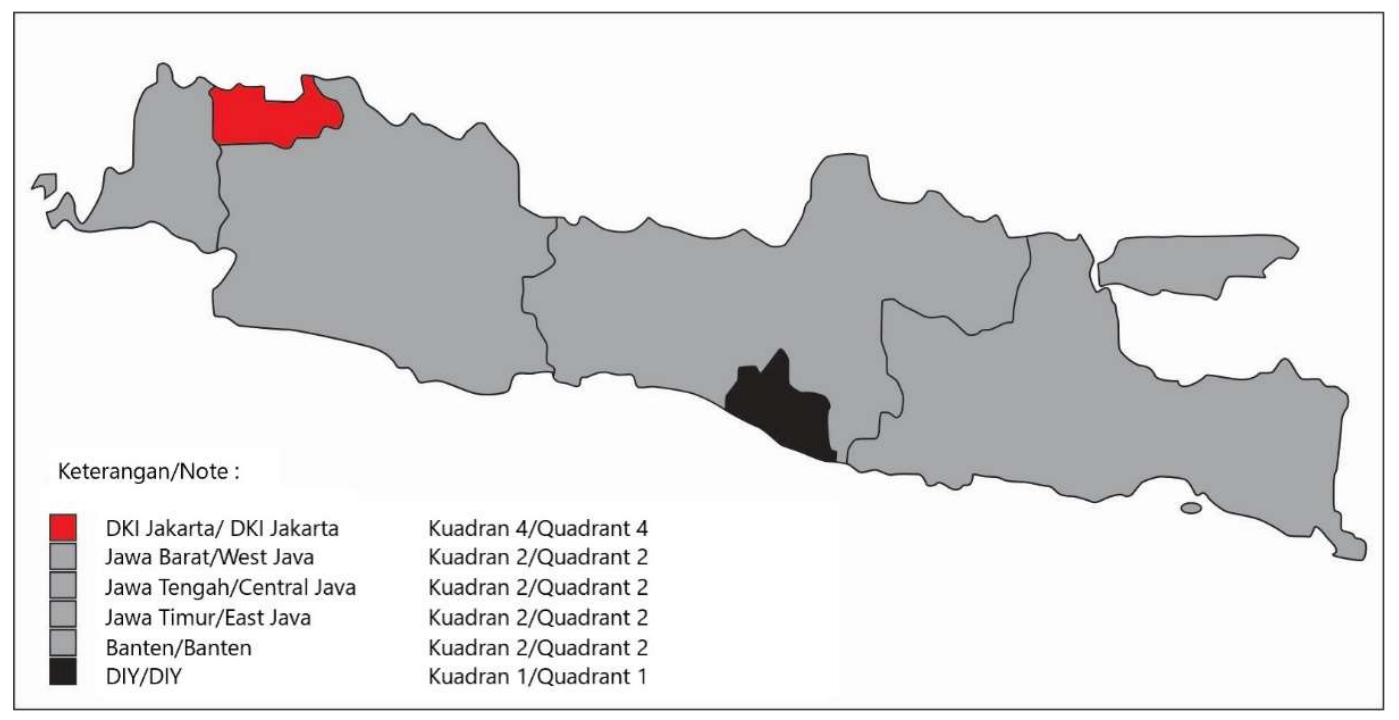

Gambar 4. Peta Daya Saing Perikanan Pulau Jawa Tahun 2000-2018.

Figure 4. Competitiveness Mapping for Fishery in Java Island in 2000-2018

Sumber: data sekunder, diolah/Source: secondary data, processed

Shift Share Esteban Marquilas dilengkapi dengan komponen tambahan jika dibandingkan dengan Shift Share klasik, yaitu komponen efek lokasi atau pertumbuhan pangsa pasar yang nantinya akan dikategorikan menjadi komponen spesialisasi dan kompetitif. Berdasarkan hasil perhitungan di sektor perikanan yang dihasilkan oleh shiftshare Esteban Marquiles pada Tabel 1 untuk beberapa provinsi di Pulau Jawa, menunjukkan bahwa Provinsi DIY berada pada kuadran 1 yang artinya daerah tersebut memiliki keunggulan kompetitif dan sudah terspesialisasi. Sedangkan untuk Provinsi Jawa Barat, Jawa Tengah, Jawa Timur dan Banten berada pada kuadran 2, artinya daerah tersebut belum memiliki daya saing namun memiliki spesialisasi. Selanjutnya, DKI Jakarta berada pada kuadran 4 , hal ini menunjukkan bahwa wilayah tersebut tergolong tidak kompetitif dan tidak terspesialisasi di sektor perikanan.

\section{1) Daerah Istimewa Yogyakarta}

Berdasarkan analisis shiftshare Esteban Marquilas di sektor perikanan tahun 2000-2018 di beberapa provinsi di Pulau Jawa menunjukkan bahwa Provinsi DIY menjadi daerah yang kompetitif, dan terspesialisasi untuk sektor perikanan hal ini dikarenakan hasil dari perhitungannya berada di kuadaran I. Hal ini terbukti dari nilai Eij-E'ij $>0$ dan nilai rij-rin $>0$. Dapat dikatakan bahwa sektor perikanan DIY mempunyai keunggulan kompetitif tahun 2000-2018. Hal tersebut didukung wilayah pesisir DIY sebelah selatan yang memiliki sumber daya kelautan bernilai ekonomi penting seperti ikan pelais besar (tuna, cakalang, marlin, lemadang), udang, tongkol, marlin, ikan pelagis dan demersal kecil (layur, kakap, manyung) dan lobster (Sahubawa, Khakim \& Lasindrang, 2015). Wilayah tersebut berada pada Kabupaten Kulon Progo, Kabupaten Bantul dan Kabupaten Gunungkidul.

2) Provinsi Jawa Barat, Jawa Tengah, Jawa Timur, dan Banten

Selanjutnya untuk wilayah Jawa Barat, Jawa Tengah, Jawa Timur, dan Banten berada di kuadaran II, yang artinya daerah tersebut tidak kompetitif tetapi terspesialisasi. Hal ini terbukti dari nilai $E \mathrm{Eij}-\mathrm{E}$ ”ij $>0$ dan nilai rij-rin $<0$. Sehingga provinsiprovinsi tersebut hanya terspesialisasi saja. Dapat dikatakan bahwa kelima provinsi ini menjadi daerah pendukung pengembangan sub sektor perikanan untuk wilayah DIY. Meski demikian, wilayah tersebut memiliki potensi untuk mengembangkan sektor perikanannya. Terbukti dengan kemampuan Provinsi Banten dalam melakukan kegiatan ekspor hasil perikanannya ke beberapa negara. Hal tersebut dapat diketahui dari data ekspor tahun 2017 sebanyak 10,9 ton ikan di ekspor ke luar negeri melalui perairan Banten (Badan Karantina dan Inspeksi Ikan Kelas II Merak), sebagian besar produk yang diekspor adalah udang. Mengenai distribusi perikanan, pola distribusi hasil tangkapan di pelabuhan perikanan di Pantai Utara (Pantura) Jawa diklasifikasikan menjadi tiga, yaitu pelaku distribusi, konektivitas dan pemasaran berbasis 
pasar. Berdasarkan pasar, pola distribusi terbagi menjadi empat klasifikasi, yaitu distribusi pasar lokal, regional, luar Jawa dan luar negeri (Gumilang et al., 2014). Dan teknologi ideal yang dikembangkan untuk penangkapan ikan di Karimunjawa adalah bubu trap dan tonda (Irnawati et al., 2011) .

Jawa Tengah memiliki kekhususan tersendiri untuk bagian wilayah utara dan selatan terkait jenis ikan yang dikonsumsi, contoh komoditas unggulan perikanan tangkap yang dapat memenuhi kebutuhan dalam negeri dan masih dapat dijual di luar Kabupaten Rembang adalah ikan petelur, ikan tenggiri dan ikan selar (Kohar \& Paramartha, 2012). - Namun di Kabupaten Pati, industri pengolahan perikanan (Usaha Kecil Menengah - UMKM) yang melibatkan proses sederhana dengan sumber daya manusia yang relatif rendah, faktor higienis dalam proses tersebut masih kurang diperhatikan sehingga menghasilkan produk akhir dengan kualitas yang kurang baik (Riyanto \& Mardiansjah, 2018). Secara kelembagaan pengelolaan perikanan berbasis ekosistem dapat dilaksanakan di Jawa Tengah, dan pengelolaan sumberdaya perikanan berbasis ekosistem memberikan indikasi yang prospektif (Susilowati, 2013).

Provinsi Jawa Timur dan Jawa Barat menerapkan perikanan on farm dan off farm. Hal tersebut tentunya akan memberikan peluang bagi daerah-daerah tersebut untuk mengoptimalkan subsektor perikanan yang menyumbang Produk Domestik Regional Bruto (PDRB) masingmasing daerah. Jawa Timur merupakan wilayah yang paling banyak diduduki oleh perairan yakni sebanyak 4 kali wilayah daratan, dengan panjang garis pantai kurang lebih $2.916 \mathrm{~km}$, dan mempunyai sumber ikan yang melimpah baik di laut maupun di darat melalui budidaya ikan (Rini \& Koswara, 2017). Di Situbondo pengolahan ikan tongkol asap diproses manual berdasarkan kearifan lokal yang dimiliki, yakni dari bahan dan tata cara produksi (Junianingsih, 2013). Pelestarian hasil pengolahan di atas, cukup penting untuk melestarikan dan mengembangkan karakteristik lokal. Di Kabupaten Lamongan, 67\% UMKM penghasil ikan asap di Pantai Utara yang merupakan beberapa olahan hasil perikanan adalah ikan asap, tepung ikan, benang sari, petis, terasi, pindang, bakso dan rajungan (Yaskun \& Sugiarto, 2017).

\section{3) DKI Jakarta}

DKI Jakarta berada di kuadaran IV yang memiliki nilai Eij-E” $\mathrm{ij}<0$ dan nilai rij-rin $<0$ dapat dikatakan bahwa DKI Jakarta untuk sektor perikanan tidak kompetitif dan tidak terspesialisasi. Hal ini dikarenakan, sub sektor perikanan tidak memiliki andil besar dibanding sektor lainnya tahun 2016, kontribusi pertanian, perikanan dan kehutanan hanya sebesar $0,09 \%$. Walaupun memiliki sumbangsih yang cukup kecil, tetapi pemerintah DKI Jakarta juga terus meningkatkan potensi sektor perikanan seperti produksi perikanan budidaya yang terdiri budidaya laut, tambak dan kolam. Upaya yang dapat dilakukan oleh otoritas DKI Jakarta adalah, sebagai berikut (Kementerian Kelautan Perikanan, 2013):

a) Mengembangkan pola ruang perairan/ pesisir berdasarkan letak pulau, potensi pengembangan sumber daya alam, dan keterkaitan antar kegiatan sosial dan ekonomi.

b) Merehabilitasi pantai / pulau yang telah terabrasi.

b) Mempertahankan dan melestarikan kawasan lindung di daratan pulau dan perairan laut.

\section{2) RCA}

RCA merupakan ukuran dari keunggulan komparatif pada komoditas suatunegara. Daya saing ekspor sektor perikanan ditujukan ke tujuh negara tujuan ekspor utama, yakni Amerika Serikat, Jepang, negara-negara ASEAN, Cina, Malaysia, Hongkong, dan Uni Eropa. Sektor perikanan Indonesia dikatakan memiliki keunggulan komparatif apabila nilai ekspor sektor perikanan lebih tinggi dari tujuh negara tujuan ekspor utama, seperti telah disebutkan sebelumnya. Nilai RCA> 1 menunjukkan Indonesia mempunyai keunggulan komparatif di atas rata-rata tujuh negara tujuan ekspor utama, sehingga dapat dikatakan daya saingnya relatif kuat. Apabila nilai $\mathrm{RCA}<1$, maka Indonesia mempunyai keunggulan komparatif di bawah tujuh negara tujuan ekspor utama. Atau dengan kata lain, sektor tersebut dinilai memiliki daya saing yang rendah.

Analisis daya saing komparatif HS 03 Indonesia dapat dilihat pada Tabel 2 memperlihatkan estimasi RCA HS 03 di dunia. Jika nilai RCA HS 03 Indonesia menunjukan nilai lebih dari satu, artinya bahwa HS 03 Indonesia mempunyai keunggulan komparatif di pasar dunia, tapi apabila RCA HS 03 Indonesia menunjukkan nilai kurang dari satu maka HS 03 Indonesia tidak memiliki keunggulan komparatif di pasar dunia. 
Tabel 2. Rata-Rata RCA Produk HS 03 Indonesia Di 7 Pasar Unggulan Tahun 2000 - 2018 Table 2. Average of RCA For Indonesian HS 03 Product In 7 Main Markets, Year Of 2000- 2018

\begin{tabular}{llcl} 
No & $\begin{array}{c}\text { Pasar Ekspor/ } \\
\text { Export Market }\end{array}$ & $\begin{array}{c}\text { Rata-rata RCA/ } \\
\text { Average RCA }\end{array}$ & Keterangan/Remarks \\
\hline 1 & China & 2.40 & Berdaya saing/Competitiveness \\
2 & Japan & 1.52 & Berdaya saing/Competitiveness \\
3 & Hongkong & 6.04 & Berdaya saing/Competitiveness \\
4 & United States & 8.13 & Berdaya saing/Competitiveness \\
5 & Malaysia & 2.86 & Berdaya saing/Competitiveness \\
6 & European Union & 1.91 & Berdaya saing/Competitiveness \\
7 & ASEAN & 3.52 & Berdaya saing/Competitiveness \\
\hline
\end{tabular}

Sumber: data sekunder, diolah/Source: secondary data, processed

Hasil analisis RCA ditunjukkan pada tabel 2. Dalam tabel 2 terlihat bahwa produk HS 03 Indonesia memiliki daya saing di semua 7 (tujuh) pasar unggulan, hal ini ditunjukkan dengan nilai RCA produk HS 03 Indonesia selalu memiliki nilai lebih dari 1. Nilai RCA Indonesia bisa lebih dari 1 dikarenakan Indonesia merupakan salah satu negara ekpsortir terbesar produk HS 03 dunia. Hasil penghitungan nilai rata-rata RCA Indonesia tahun 2000-2018 di pasar unggulan menunjukkan bahwa nilai rata-rata RCA secara berturut-turut ditempati oleh Amerika Serikat $(8,13)$, Hongkong $(6,04)$, ASEAN $(3,52)$, Malaysia $(2,86)$, Tiongkok $(2,40)$, Uni Eropa $(1,91)$, dan Jepang $(1,52)$.

\section{a. Amerika Serikat}

Amerika Serikat menjadi pasar dengan nilai rata-rata RCA terbesar yaitu 8.13. Hal ini berbanding lurus dengan rata-rata total ekspor HS 03 Indonesia ke Amerika yang mencapai 33\% dari total ekspor HS 03 Indonesia. Produk perikanan Indonesia yang banyak diminati di pasar Amerika adalah udang-udangan dengan nilai impor pada tahun 2018 mencapai 1.030.349 ribu USD atau sekitar $65 \%$ dari total ekspor HS 03 Indonesia ke Amerika.

\section{a. Hongkong}

Hasil penghitungan nilai rata-rata RCA HS 03 Indonesia di Hong Kong menunjukkan nilai 6,04 sehingga dapat diartikan bahwa produk HS 03 Indonesia di Hongkong memiliki daya saing komparatif. Keunggulan komparatif HS 03 Indonesia di Hongkong didukung oleh peningkatan ekspor ikan kerapu. Share nilai impor kerapu Hong Kong dari Indonesia dalam periode 2001-2017 rata-rata mencapai $23,77 \%$ dari total impor kerapu Hong Kong, Indonesia menempati posisi ke 2 setelah Philipina sebagai eksportir kerapu di Hong Kong dan rata-rata pertumbuhan pertahun sebesar 3,5 $\%$ (ITC, 2020).

\section{c. ASEAN}

Hasil perhitungan rata-rata RCA produk HS 03 Indonesia ke ASEAN menunjukkan nilai 3,52. Dengan demikian, Indonesia dapat dikatakan memiliki daya saing komparatif. Pasar utama Indonesia untuk produk HS 03 adalah Vietnam, Malaysia, Singapura, Thailand dan Filipina. Nilai ekspor produk tahun 2000-2018 berkisar 400.000 ribu USD dan mampu memenuhi kurang lebih $10 \%$ dari total kebutuhan di ASEAN. Di tingkat ASEAN atau ASEAN-China, produk perikanan Indonesia yang memiliki daya saing tinggi adalah produk dengan kode HS 03 (ikan, udang, moluska, avertebrata akuatik), namun Indonesia masih memiliki kelemahan dalam komoditas ekspor bernilai tambah (Saptanto, 2011).

\section{d. Malaysia}

Hasil perhitungan rata-rata RCA produk HS 03 Indonesia ke Malaysia diperoleh nilai 2,86. Dengan demikian, Indonesia dapat dikatakan memiliki daya saing komparatif. Indonesia merupakan salah satu pemasok produk perikanan di Malaysia yang menyumbang sekitar $14 \%$ kebutuhan ikan Malaysia. Ikan kerapu merupakan produk yang paling disukai di Malaysia (Ismi, 2006).

\section{e. Tiongkok}

Hasil perhitungan rata-rata RCA produk HS 03 Indonesia ke China diperoleh nilai 2,40. Dengan demikian, Indonesia dapat dikatakan memiliki daya saing komparatif. China merupakan importir terbesar kedua setelah Amerika Serikat yang ekspornya mencapai 15 miliar USD pada 2018. Selain itu, China juga menjadi eksportir terbesar produk HS 03 dunia dengan nilai ekspor mencapai 
12 miliar USD pada 2018. Indonesia hanya bisa menjual produknya untuk 542 juta USD atau sekitar $4,5 \%$ dari total impor China. Produk yang paling disukai adalah jenis Mollusca, seperti cumi-cumi, sotong, dan gurita. Pada periode Januari hingga September, nilai ekspor cumi-cumi, sotong dan gurita ke China mencapai 371 juta USD atau setara dengan $10 \%$ dari total ekspor perikanan Indonesia (Direktorat Jenderal Penguatan Daya Saing Produk Kelautan dan Perikanan, 2018).

\section{f. Uni Eropa}

Hasil perhitungan rata-rata RCA produk HS 03 Indonesia ke Uni Eropa menunjukkan nilai 1,91. Dengan demikian, Indonesia dapat dikatakan memiliki daya saing komparatif. Menurut Kementerian Kelautan dan Perikanan (KKP), secara umum pertumbuhan nilai ekspor perikanan Indonesia ke Uni Eropa periode 2012-2018 meningkat $3,44 \%$. Pada tahun 2018 , nilai ekspor komoditas Tuna mencapai USD 118 juta, udang USD 97,47 juta, cumi-cumi, cumi-cumi, dan gurita USD 93,85 juta USD, dan kepiting USD 15,59 juta.

\section{g. Jepang}

Hasil perhitungan rata-rata RCA produk HS 03 Indonesia ke Jepang menunjukkan nilai 1,52. Dengan demikian, Indonesia dapat dikatakan memiliki daya saing komparatif. Dalam kurun waktu 2016-2018, ekspor HS 03 dari Indonesia ke Jepang cenderung meningkat jika dibandingkan tahuntahun sebelumnya. Komoditas unggulan yang akan diekspor ke Jepang adalah udang, tuna, cakalang, tongkol, kepiting dan cumi-cumi, sotong, gurita (Kementerian Kelautan dan Perikanan, 2018).

\section{h. EPD}

Metode analisis Export Product Dynamics (EPD) digunakan untuk mengetahui posisi daya saing produk atau komoditi suatu negara atau wilayah untuk tujuan pasar tertentu. Posisi ideal pada analisis ini adalah pada kategori rising stars artinya negara tersebut memperoleh tambahan pangsa pasar pada produk mereka yang bertumbuh cepat (fast-growing products). Analisis EPD yang dilakukan dalam penelitian ini melihat rata-rata kedinamisan ekspor produk HS 03 Indonesia pada tahun 2000 - 2018 di 7 (tujuh) pasar unggulan. Hasil analisis EPD produk HS 03 Indonesia ditunjukkan pada tabel 3 dan gambar 2 .

Tabel 3 dan gambar 2, menerangkan bahwa kedinamisan produk HS 03 Indonesia selama tahun 2000 - 2018 mempunyai nilai rising star pada pasar Malaysia, Tiongkok dan Amerika Serikat, sedangkan pasar Uni Eropa, Hong Kong dan Jepang mempunyai nilai retreat, dan pasar ASEAN mempunyai nilai lost opportunity. Pada pasar Malaysia, Tiongkok, dan Amerika Serikat nilai rata-rata EPD produk HS 03 Indonesia berada pada posisi rising star, hal ini menandakan bahwa pangsa pasar produk total dan pangsa produk HS 03 Indonesia di pasar tersebut mengalami pertumbuhan yang positif. Artinya produk-produk ekspor Indonesia berkomepetitif dan produk HS 03 Indonesia dinamis di pasar Malaysia, Tiongkok, dan Amerika Serikat. Pada pasar ASEAN nilai rata-rata EPD produk HS 03 Indonesia berada pada posisi lost opportunity, hal ini menunjukkan bahwa pangsa pasar produk total Indonesia mengalami pertumbuhan yang negatif dan pangsa pasar produk HS 03 Indonesia mengalami pertumbuhan yang positif. Artinya produk-produk ekspor Indonesia di ASEAN tidak kompetitif akan tetapi produk HS 03 berisfat dinamis. Pada pasar Uni Eropa, Hong Kong, dan Jepang nilai rata-rata EPD produk HS 03 Indonesia berada pada posisi retreat, hal ini menunjukkan bahwa pangsa pasar produk total dan pangsa pasar produk HS 03 Indonesia mengalami pertumbuhan yang negatif. Artinya produk-produk ekspor Indonesia tidak kompetitif dan produk HS 03

Tabel 3. Rata-rata EPD Produk HS 03 Indonesia Di 7 Pasar Unggulan Tahun 2000 - 2018

Table 3. Average EPD for Indonesian HS 03 Products in Seven Prime Markets in 2000-2018

\begin{tabular}{llccl}
\hline No & Negara/Country & $\begin{array}{c}\text { Pertumbuhan Pangsa Eksporl } \\
\text { The Groeth of Export Share }\end{array}$ & $\begin{array}{c}\text { Pertumbuhan Pangsa Produk/ } \\
\text { The Growth Product Share }\end{array}$ & $\begin{array}{c}\text { Nilail } \\
\text { Score }\end{array}$ \\
\hline 1 & Tiongkok & 0.000086 & 0.000011 & Rising star \\
2 & Jepang & -0.000073 & -0.000035 & Retreat \\
3 & Hongkong & -0.000019 & -0.000007 & Retreat \\
4 & Amerika Serikat & 0.000115 & 0.0000008 & Rising star \\
5 & Malaysia & 0.000037 & 0.000060 & Rising star \\
6 & Uni Eropa & -0.000011 & -0.000003 & Retreat \\
7 & ASEAN & -0.000173 & 0.000055 & Lost Opportunity \\
\hline
\end{tabular}

Sumber: data sekunder, diolah/Source: secondary data, processed 


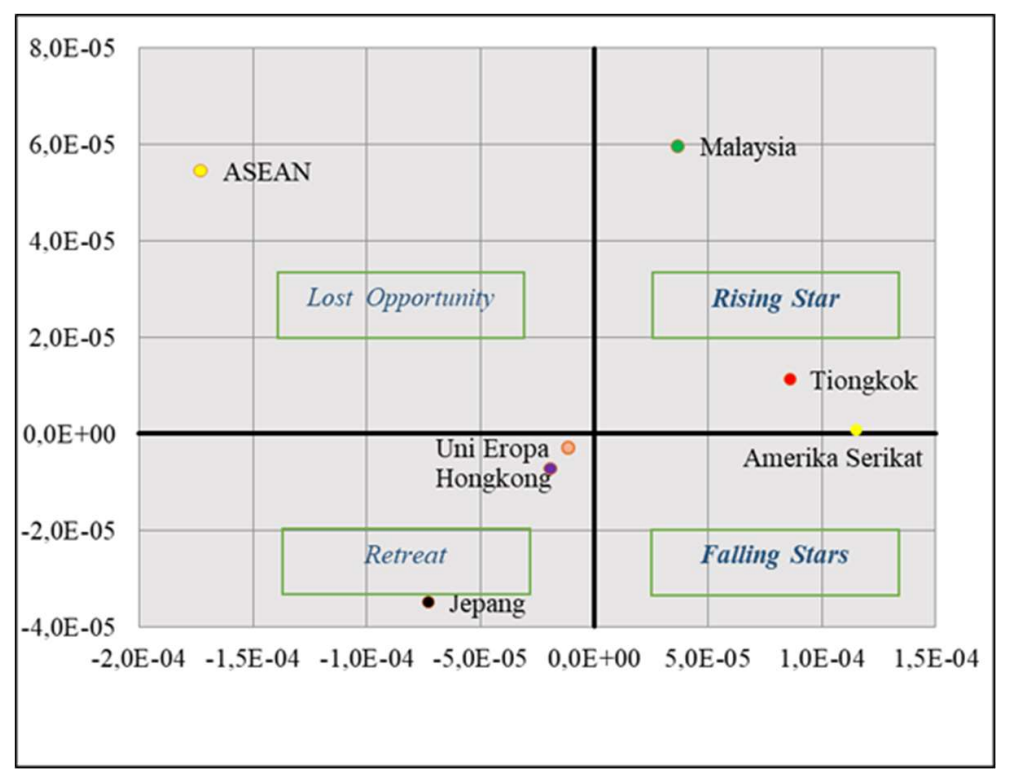

\section{Gambar 5. Rata-rata EPD Produk HS 03 Indonesia Di Tujuh Pasar Unggulan Tahun 2000 - 2018. Figure 5. Average EPD for Indonesian HS 03 Products in Seven Prime Markets in 2000-2018 \\ Sumber: data sekunder, diolah/Source: secondary data, processed}

Indonesia tidak dinamis atau stagnan di pasar Uni Eropa, Hong Kong, dan Jepang. Produk perikanan Indonesia yang mengalami kehilangan peluang adalah HS 030246 (Ikan, asin dan dalam air asin, tetapi tidak dikeringkan atau diasapi), HS 030273 (Ikan mas, hidup), HS030326 (Tunas, segar atau dingin, tidak termasuk pos 03.04, hati dan telur), HS 030365 (Salmonidae, nes, beku, tidak termasuk pos 03.04, hati dan telur), HS 030569 (Ikan, diasapi termasuk fillet) dan HS 030721 (Crustacea nes, tidak beku, dalam cangkang atau tidak, termasuk direbus dalam cangkang) (Laksani \& Jati, 2017). Ekspor perikanan ke pasar Uni Eropa telah dipengaruhi oleh larangan ekspor domestik, perubahan struktural domestik, dan fluktuasi nilai tukar daripada penolakan perbatasan (Bose et al., 2019).

\section{KESIMPULAN DAN REKOMENDASI KEBIJAKAN}

\section{Kesimpulan}

Daerah yang memiliki keunggulan daya saing perikanan adalah DIY, karena dalam kurun waktu 2000-2018 berada pada kuadran 1 jika dibandingkan dengan provinsi lain di pulau Jawa. Sedangkan provinsi Jawa Barat, Jawa Tengah, Jawa Timur, dan Banten berada pada kuadran 2, yang berarti daerah-daerah tersebut belum memiliki daya saing namun memiliki spesialisasi. Selanjutnya, DKI Jakarta berada pada kuadran
4, hal ini menunjukkan bahwa wilayah tersebut tergolong tidak kompetitif dan tidak terspesialisasi di sektor perikanan. Dari sisi daya saing Indonesia di bidang perikanan, Indonesia merupakan salah satu eksportir produk HS 03 terbesar di dunia dan produk perikanannya pada tahun 2000 - 2018 telah diakui sebagai rising star untuk pasar Malaysia, China dan Amerika Serikat.

\section{Rekomendasi Kebijakan}

Subsektor perikanan memiliki potensi besar karena keterkaitan dari sumber daya alamnya yang besar sehingga akan mampu menghasilkan produk dan jasa dengan daya jual yang tinggi. Hal ini bisa sebagai sektor unggulan dan penggerak utama (prime mover) pembangunan perekonomian daerah, begitu juga di Provinsi DKI Jakarta yang maju, mandiri dan sejahtera. Kondisi ini bisa terwujud dengan dilakukan sinergi antara masyarakat dan pemerintah dalam rangka percepatan pembangunan subsektor perikanan di Provinsi DKI Jakarta. Proses perencanaan pemerintah di bidang subsektor perikanan yang lebih efisien akan mewujudkan informasi yang akurat hal tersebut bermanfaat untuk meningkatkan dan juga menarik investor dalam penanaman modal di subsektor perikanan Provinsi D.K.I Jakarta. Kondisi tersebut akan mendorong pembangunan Provinsi D.K.I Jakarta di subsektor perikanan baik dibidang usaha perikanan tangkap, budidaya, pengolahan dan pemasaran serta kegiatan-kegiatan usaha lainnya. 


\section{UCAPAN TERIMA KASIH}

Ucapan terima kasih penulis sampaikan kepada Direktorat Jenderal Penguatan Riset dan Pengembangan, Kementerian Riset, Teknologi, dan Pendidikan Tinggi yang telah memberikan dana dalam penelitian ini. Serta ucapan terima kasih kepada seluruh penyedia informasi dan data penelitian.

\section{PERNYATAAN KONTRIBUSI PENULIS}

Dengan ini kami menyatakan bahwakontribusi masing-masing penulis terhadap pembuatan karya tulis adalah: Andhatu Achsa sebagai kontributor utama, Rian Destiningsih, Yustirania Septiani dan Dian Marlina Verawati sebagai kontributor anggota. Penulis menyatakan bahwa telah melampirkan surat pernyataan kontribusi penulis.

\section{DAFTAR PUSTAKA}

Amarullah, T. (2017). Strategi Peningkatan Produktifitas Perikanan Tangkap Skala Kecil Yang Berkelanjutan Di Kabupaten Aceh Jaya Provinsi Aceh. Jurnal Perikanan Tropis, 4(1), 11-21.

Arifin, S., Rae, D. E., \& Joseph, C. P. R. (2007). Kerjasama Perdagangan Internasional: Peluang dan Tantangan bagi Indonesia. Elex Media Komputindo.

Badan Pusat Statistik Indonesia. (2020). Statistik Indonesia 2020. In Statistical Yearbook of Indonesia. Badan Pusat Statistik Indonesia. https://doi.org/10.3389/fpsyg.2015.00002

Bose, S., Al Naabi, A. M. R., Boughanmi, H., \& Yousuf, J. B. (2019). Domestic Ban Versus Border Rejections: A Case of Oman's Fish Exports to the EU. SAGE Open, 9(1), 1-12. https://doi. org/10.1177/2158244018823079

Direktorat Jenderal Penguatan Daya Saing Produk Kelautan dan Perikanan. (2018). Kinerja Ekspor Produk Perikanan Indonesia Tahun 2018. Direktorat Jenderal Penguatan Daya Saing Produk Kelautan Dan Perikanan. https://kkp. go.id/djpdspkp/artikel/7947-kinerja-ekspor-produk-perikanan

Direktorat Kelautan dan Perikanan. (2016). Kajian Strategi Industrialisasi Perikanan Untuk Mendukung Pembangunan Ekonomi Wilayah.

Gumilang, A. P., Solihin, I., \& Wisudo, S. H. (2014). Pola Distribusi Dan Teknologi Pengelolaan Hasil Tangkapan Pelabuhan Perikanan DI Wilayah Pantura Jawa. Jurnal Teknologi Perikanan Dan Kelautan, 5(1), 65-74.

Imelda, Kusrini, N., \& Hidayat, R. (2019). Strategi Pengelolaan Perikanan Tangkap Berkelanjutan Di Wllayah Pesisir Kabupaten Kubu Raya. Marine Fisheries, 10(1), 59-69.
Indonesia, B. P. S. R. (2019). Analisis Komoditas Ekspor 2012-2018 Sektor Pertanian, Industri, dan Perdagangan.

Irnawati, R., Simbolon, D., Wiryawan, B., Murdiyanto, B., \& Nurani, T. W. (2011). Analisis Komoditas Unggulan Perikanan Tangkap Di Taman Nasional Karimunjawa. Jurnal Saintek Perikanan, 7(1), $1-9$.

Ismi, S. (2006). Usaha Pendederan Benih Kerapu Macan (Epinephelus Fuscoguttatus). Media Akuakultur, 1(3), 97-102.

Junianingsih, I. (2013). Analisis Profitabilitas Usaha Pengolahan Tradisional Ikan Tongkol Asap Di Desa Jangkar Kabupaten Situbondo. Samakia : Jurnal IImu Perikanan, 4(2), 86-93.

Kementerian Kelautan dan Perikanan. (2018). Refleksi 2018 dan Outlook 2019. Kementerian Kelautan dan Perikanan.

Kementerian Kelautan Perikanan. (2013). Profil Kelautan Dan Perikanan Provinsi DKI Jakarta Untuk Mendukung Industrialisasi.

Laksani, D. D., \& Jati, K. (2017). Analisis Hambatan Tarif Dan Non Tarif Serta Pengembangan Pasar Eropa Pada Produk Perikanan Indonesia. Jurnal Analis Kebijakan, 1(2), 49-60. https://doi.org/10.1017/ CBO9781107415324.004

Kohar M, A. \& Paramartha, D. (2012). Analisis Komoditas Unggulan Perikanan Tangkap Di Kabupaten Rembang. Jurnal Harpodon Bornei, 5(2), 161-171.

Malau, M. T. (2014). Aspek Hukum Peraturan Dan Kebijakan Pemerintah Indonesia Menghadapi Liberalisasi Ekonomi Regional " Masyarakat Ekonomi ASEAN 2015. Jurnal Rechtsvinding: Media Pembinaan Hukum Nasional, 3(2), 163-182. https://doi.org/10.1017/CBO9781107415324.004

Ridhwan, M. M., Wicaksono, G., Nurliana, L., Bary, P., Suryani, F. T., \& Satyanugroho, R. (2015). Analisis Daya Saing Dan Strategi Industri Nasional Di Era Masyarakat Ekonomi Asean Dan Perdagangan Bebas. In Working Paper (Vol. 3). https://www. bi.go.id/id/publikasi/wp/Documents/Analisis Daya Saing dan Strategi Industri Nasionak di Era Masyarakat Ekonomi ASEAN dan Perdagangan Bebas.pdf

Rini, F. P., \& Koswara, A. Y. (2017). Faktor Penentu Lokasi Sentra Industri Kecil Pengolahan Hasil Perikanan Tangkap di Kawasan Pesisir Kota Pasuruan. Jurnal Teknik ITS, 6(2), 2-6. https:// doi.org/10.12962/j23373539.v6i2.25016

Risma, O. R., Zulham, T., \& Dawood, T. C. (2018). Pengaruh Suku Bunga, Produk Domestik Bruto Dan Nilai Tukar Terhadap Ekspor Di Indonesia. Jurnal Perspektif Ekonomi Darussalam, $4(2), \quad 300-317 . \quad$ https://doi.org/10.24815/jped. v4i2.13027

Riyanto, S., \& Mardiansjah, F. H. (2018). Pengembangan Industri Pengolahan Perikanan Dalam 
Pengembangan Ekonomi Lokal. Jurnal Litbang: Media Informasi Penelitian, Pengembangan Dan IPTEK, 14(2), 107-118. https://doi.org/10.33658/ jl.v14i2.113

Sahubawa, L., Khakim, N., \& Lasindrang, M. (2015). Kajian Sebaran Potensi Ekonomi Sumber Daya Kelautan Di Pantai Selatan Daerah Istimewa Yogyakarta Sebagai Upaya Percepatan Investasi. Jurnal Teknosains, 4(2), 101-120.

Salvatore, D. (2014). Ekonomi Internasional. Salemba Empat.

Saptanto, S. (2011). Daya Saing Ekspor Produk Perikanan Indonesia. Jurnal Sosek KP, 6(1), 51-60.

Sarwono, \& Pratama, W. (2014). Analisis Daya Saing Kedelai Indonesia. Journal of Economics and Policy, 7(2), 109-120. https://doi.org/10.15294/ jejak.v7i1.3596

Susilowati, I. (2013). Prospek Pengelolaan Sumber Daya Perikanan Berbasis Ekosistem: Studi Empiris Di Karimunjawa. Jurnal Ekonomi Pembangunan, 14(1), 16-37. https://doi.org/10.23917/jep. v14i1.148

Triarso, I. (2012). Potensi dan Peluang Pengembangan Usaha Perikanan Tangkap Di Pantura Jawa Tengah. Jurnal Saintek Perikanan, 8(1), 65-73. https://doi.org/10.14710/ijfst.8.1.65-73

Wulansari, E., Yulianto, E., \& Pangestuti, E. (2016). Pengaruh Jumlah Produksi, Harga Internasional, Nilai Tukar Dan Tingkat Suku Bunga Terhadap Tingkat Daya Saing Ekspor Kelapa Sawit Indonesia (Studi Pada Tahun 2009-2013). Jurnal Administrasi Bisnis (JAB), 39(2), 176-184.

Yaskun, M., \& Sugiarto, E. (2017). Potensi Hasil Perikanan Laut Terhadap Kesejahteraan Para Nelayan Dan Masyarakat Di Kabupaten Lamongan. Jurnal Studi Manajemen Dan Bisnis, 4(1), 257-264. https://doi.org/10.30736/jpensi.v2i1.91 